\title{
The Role of Women Farmer Group in Increasing Family Welfare
}

\author{
${ }^{1}$ MAUDIA CAMALIN, 2 IWAN SETIAWAN \\ 1,2 Fakultas Pertanian, Universitas Padjadjaran, Jl.Raya Bandung Sumedang Km.21 Jatinangor 45363 \\ email: ${ }^{1}$ mcamalin@gmail.com; 2 i.setiawan@unpad.ac.id
}

\begin{abstract}
The cross-sector inequality puts farmers in Sumedang at the lowest level of welfare. Agricultural institutions, particularly the Women Farmer Group (KWT), is formed to increase the level of farmer's family welfare through women as the booster. The aim of starting KWT Mekar Arum is to relieve poverty which is the main social problem in Margaluyu Village, Tanjungsari Sub-district, Sumedang Regency. This research is intended to describe KWT role in increasing the level of the member's family welfare. It is a qualitative designed research with a case study method. The research result shows that the group has a social role for its members. Facilitation in production input, capital, and marketing are carried out by the group in working its role on developing member's businesses. By joining the group, the increase in welfare occurs in terms of income, health, and education of the KWT Mekar Arum.
\end{abstract}

Keywords: Role, Women Farmer Group, Increasing Level of Family Welfare.

\section{Introduction}

The contribution of the agricultural sector to GDP Indonesia remains significant $(13.5 \%)$, since it absorbs about 38 million workers or $33 \%$ of the total Indonesian working population. The problem is, when compared to the labor conditions in other sectors, the labor of the agricultural sector is at the lowest level of welfare (BPS, 2016). Furthermore, the labor conditions of the agricultural sector are also large (60\%) in old condition (aging), that make it less productive and less responsive to the innovation of science and technology (Setiawan, 2015). These conditions have had an impact on weak institutional and labor bargaining positions in the agricultural sector. Ironically, the condition does not necessarily gain favor from the whole agricultural institution.

Benjamin White (1979) in Wiradi (2009: 238) asserted that the main problem of Indonesia's agricultural sector lies in institutional aspects, both as an institution and social capital. Weakening of siding with the policymakers, unorganized agricultural main actors, agricultural (agro-industry) businessmen that are not growing, actors of agricultural innovation in commercialization that are not independent, partners inconsistency, and weak commitment and trust in enforcing agreements, are a series of facts that occurred in Indonesian agricultural institutions. Explicitly, the mass media has not been siding with women, especially rural women dominated by women farmers (Yulianita, 2001). Therefore, it is important to strengthen them. Normatively, the importance of it has been affirmed in Law No. 19/2013 on the Protection and Empowerment of Farmers and Strategic Plans of Agricultural Ministry 2015-2019.

In real terms, there are many identified and potential agricultural institutions that potentially have significant roles for improving the bargaining position of farmers and welfare of their families. One of them is Women Farmer Group (KWT). Law No. $19 / 2013$ in article 69 confirms that "The Government and the Regional Government in accordance with their authority are obliged to encourage and facilitate the establishment of Farmers Institutional and Farmers' Economic Institutions", and KWT can be regarded as one of that institutions. The mapping results of Sri Hidayati Djoeffan (2001) revealed a

Received: June 05, 2017, Revision: August 23, 2017, Accepted: December 20, 2017

Print ISSN: 0215-8175; Online ISSN: 2303-2499. DOI: http://dx.doi.org/10.29313/mimbar.v33i2.2599.350-360

Accredited B based on the decree No.040/P/2014, valid on February, 18, 2014 until February, 18, 2019. Indexed by DOAJ, Sinta, IPI 
high increase in women's movement in the late $21^{\text {st }}$ century. Mehra (1995); Esim \& Mehra (1998), Renyasih et al. (2004), Setiawan (2006) and Vitayala (2010) emphasize that in the last twenty years there has been a significant increase in women's contribution to the agricultural sector, both in production activities on land and in household activities.

Researcher Tara Satyavathi et al. (2010) in India revealed that woman farmers play an important role in agricultural activities ranging from production to marketing of farm products. There is a tendency, from year to year, the increasing role of women that ultimately exceeded men. Ervinawati et al. (2015) asserted that woman farming is not only contributing to farming, but has become the backbone of the family in fulfilling the economic needs of the family. The problem is, both in Asia and in Africa, although the role of women in agriculture is significant, women are identical with unpaid labor (Terri Raney et al., 2011). Similarly to women farmers in Indonesia, despite having multiple roles as housewives and laborers in the agricultural sector, they have a weak bargaining power and socioeconomic status. Therefore, they seek to improve their bargaining position, status, and efforts to meet the economic needs of their families through agricultural activities and other productive economies organized in KWT.

One of the KWT established in order to strengthen the bargaining position of women farmers and realizing the welfare of family farmers is KWT Mekar Arum in Margaluyu Village, Tanjungsari Sub-district. Tanjungsari is the third sub-district that has poverty problems. Now KWT Mekar Arum becomes the most superior KWT in Tanjungsari Subdistrict, because the economic turnaround and group activities have been running continuously. Margaluyu Village, with poverty as a major social problem (Pemerintah Desa Margaluyu, 2016), has made KWT a means to alleviate poverty, especially the poor who have been highly dependent on agriculture. The existence of KWT Mekar Arum becomes an interesting phenomenon to be studied amid the condition of most of KWT in Indonesia, particularly in West Java and Sumedang Regency, which are not active.

The phenomenon of KWT Mekar Arum is expected to be used as an example (pilot project) in Sumedang Regency that displays abnormal (positive) performance. The agricultural sector of Sumedang Regency is the main contributor to PDRB (28.03\%), but at the same time, it is also a major contributor to the low (1.15\%) rate of Economic Growth Rate (LPE) Sumedang Regency (BPS Kabupaten Sumedang, 2014). That is, when compared to labor in other sectors, labor welfare (farmers and farm workers) in Sumedang are in a very low condition. The question would be: what causes KWT Mekar Arum to develop? And how KWT Mekar Arum play its role? This study aims to: (1) describe the social role of KWT Mekar Arum; (2) describe the role of KWT Mekar Arum in the development of member's business; and (3) describe the role of KWT Mekar Arum in improving member's family welfare.

\section{Methods}

The research was designed qualitatively with a case study method. The location of the research was in KWT Mekar Arum, Margaluyu Village, Tanjungsari Sub-district, Sumedang Regency with criteria as a group capable of exploiting internal opportunities (local potential) and external (government policy). There are two data collected, which are the primary data (the result of in-depth interviews with informants and field observation results) and secondary data (obtained through documentation, literature, and archives from relevant agencies including the village, extension, and related group). Informants in this study consisted of members of KWT Mekar Arum that determined through snowball sampling, companion of KWT, and community leaders of Margaluyu Village. Data collection techniques consist of in-depth interviews, field observations, documentation studies, and triangulation. Data analysis uses Miles \& Huberman model which is an analysis data consisting of a series of activities ranging from reduction data, display data, and conclusion drawing or verification.

The role of KWT Mekar Arum which will be described through this research consists of the social role, role in business development, and the role in improving member's family welfare. The social role consists of: (1) KWT as a platform and psychological space for the members; (2) growers of social solidarity; (3) members' security provider; (4) awards for the roles of each member; and (5) the means of achieving goals. Roles in business development consist of: (1) facilitating the provision of production inputs; (2) facilitation of capital; and (3) marketing facilitation. Then the last is the role in improving family welfare 
in terms of: (1) increasing family income; (2) fulfillment of education fee; (3) fulfillment of health fee; and (4) improving the quality of relationships among family members and family functions as an implication of member business development.

\section{Overview of Research Sites}

Margaluyu Village is one of the twelve villages located in Tanjungsari Sub-district, Sumedang Regency, of West Java Province. Topographically, Margaluyu Village includes a sloping area with hilly and bumpy terrain contours. As big as 56.5 ha from 133.5 ha is the area of Margaluyu Village rice field. In general, the typology of Margaluyu Village consists of rice fields, cultivation, settlement, and public facilities in the form of buildings and rural roads (Table 1 ).

\section{Table 1}

\section{Natural Resources Potential} of Maluyu Village

\begin{tabular}{llll}
\hline No. & Natural Resources & Area & Unit \\
\hline 1 & Rice Fields & 56.5 & ha \\
2 & Fields & 39.02 & ha \\
3 & Residential Land & 47.99 & ha \\
4 & River & 1 & bh \\
5 & National Road & 0,1 & $\mathrm{~km}$ \\
6 & Village Road & 4 & $\mathrm{~km}$ \\
7 & Alley Road & 2.5 & $\mathrm{~km}$ \\
8 & Gutter & 6.8 & $\mathrm{~km}$ \\
9 & Water Spring & 1 & piece \\
10 & Football Field & - & piece \\
12 & Public Cemetry & 0,04 & ha \\
\hline
\end{tabular}

Source: Pemerintah Desa Margaluyu, 2016

Productive agricultural land in Margaluyu Village is in the form of rice fields with irrigation system largely dependent on the rain (rainfed). Therefore, palawija, rice and upland rice, corn and yams are the most cultivated commodities of Margaluyu Village farmers. The condition of land that depends on the rain makes the farming cannot be done intensively every year. The implication is that when the dry season comes, most people migrate to the informal sector in urban areas. Compared to other villages in Margamulya Village, Cijolang Village, Cijotang, and Jelekong are the areas with the most potential for agriculture and livestock. Demographically, the population of the village of Margaluyu has a total of 4,630 people with the composition of 2,303 males and 2,327 females. Quantitatively, the population of 1,618 people belongs to a productive age.

\section{Overview of Research Focus}

Small holder Income Development Improvement Program (P4K) formed by the Ministry of Agriculture of Indonesian Republic is the forerunner to the formation of KWT Mekar Arum. Under the initial name of the Small Farmer Group (KPK), Mekar Arum group from Cijolang Village received three business joint credit programs over three periods (1998-2000) of fund disbursement by Bank Rakyat Indonesia (BRI). Post-vacuum in 2000-2002, by the initiative of the board, the group decided to restart their activities by turning the group's capital through savings and loans.

The group's efforts to obtain aid resulted in the form of credit assistance cooperation with the Tanjungari Sub-district Management Unit (UPK) through the Women's Savings and Loan Fund (SPP), Kemendagri's National Self-Empowerment Program. Since 2008, nine credit disbursements have been held. Until now, KWT Mekar Arum is still working with UPK Tanjungsari in doing savings and loan activities. It is similar to the savings and loan activities of the women's group developed by M. Yunus in Bangladesh.

The Sustainable Food Estate Program (KRPL) which started in 2016 is an activity being intensified by the group through the use of the yard as the family's nutrition fulfillment and life stall. KWT Mekar Arum, through the Technical Implementation Unit (UPT) of Agriculture and Food Security Tanjungsari Sub-district, facilitates members in the utilization of the yard ranging from the provision of inputs in the form of seeds to the marketing products of each group member's yard.

KWT Mekar Arum which was confirmed on August 11, 2015 based on Decree of Village Head of Margaluyu Number 250/ Kep.04/DS/VIII/2015 has purposes of: (1) as a platform or place of learning together/ exchange of understanding; (2) to increase the knowledge and skills of members in the utilization of the yard (as a living stall); and (3) increasing the income and welfare of members through savings and loans and processing of agricultural products. Until 2017, KWT Mekar Arum has only 36 members. Of these, 16 members were mobilized as research informants with the following characteristics (Table 2).

Table 2

Research Informants

\begin{tabular}{llll}
\hline No & Name & Age & Status \\
\hline 1 & Lilis Ciyarsih & 41 & Head of KWT \\
2 & Tati Yulianti & 54 & Treasurer
\end{tabular}




$\begin{array}{llll}3 & \text { Nia Kurniasih } & 41 & \text { Secretary } \\ 4 & \text { Isum Sumanah } & 44 & \text { Public Relation } \\ 5 & \text { Iam Mariyam } & 53 & \text { Yard } \\ 6 & \text { Juju Juariah } & 44 & \text { Marketing } \\ 7 & \text { Rini } & 42 & \text { Active } \\ 8 & \text { Yani } & 41 & \text { Active } \\ 9 & \text { Dedah } & 39 & \text { Active } \\ 10 & \text { Juju Jubaedah } & 47 & \text { Active } \\ 11 & \text { Odah } & 57 & \text { Active } \\ 12 & \text { Patimah } & 50 & \text { Active } \\ 13 & \text { Ningsih } & 60 & \text { Active } \\ 14 & \text { Ati } & 59 & \text { Active } \\ 15 & \text { Oom } & 58 & \text { Active } \\ 16 & \text { Ira Rohyani } & 26 & \text { Passive }\end{array}$

Source: Primary Data of Interview Result

Activities at KWT Mekar Arum include: (1) regular meetings, held every 15 th or at the beginning of the third week of each month, take place at the secretariat of KWT Mekar Arum, the residence of the chairman, Lilis Ciyarsih (41), RT 02 RW 10, Cijolang Village. The matters discussed in the regular meetings are about the group finance including cash, savings, savings and loans, and the Group's Net Income Business (SHU); (2) the management of KRPL, in addition to vegetable seed support, through the government fund of $15,000,000$ rupiah. It also obtained 40 indigenous tilapia fish and its feed, built a nursery garden with an area of five bricks or $70 \mathrm{~m}^{2}$ located on the land owned by the chairman, and three demonstration plot scattered in the area of RT 02 Cijolang Village, covering: Tonggoh demonstration plot, with an area of one brick plant land (14 $\mathrm{m}^{2}$ ), Lebak demostration plot with an area of six bricks $\left(84 \mathrm{~m}^{2}\right.$ ) including four bricks (56 $\mathrm{m}^{2}$ ) area of fish pond demonstration plot, and demonstration plot of Ibu Nia with an area of one brick $\left(14 \mathrm{~m}^{2}\right)$ of planting land.

Besides aiming to meet the nutritional needs of the family, the use of yardland also aims to provide benefits to the family member's economy through the sale of crops from the plants grown. Through one member who is in charge of marketing, the money from the member's private yards will be received directly at the time of the transaction. Sixty percent of the sale of demonstration plots, fish ponds, and nursery gardens will be distributed to each person in charge in the form of Net Income Business ( $\mathrm{SHU}$ ) distributed at the end of each year, 30 percent set aside for group cash, and 10 percent for the owner of each demonstration plot; (3) savings and loans, savings and loan activities have been ongoing since the establishment of the group in 1998.

Currently, savings and loan KWT Mekar Arum is divided into two types of Savings and Loans Group and Savings and Loans UPK. Group savings and loan funds come from principal savings, mandatory savings, voluntary savings, capital, Mandatory Borrower Savings (SWP), and SHU runs, while UPK savings and loan funds come from the PNPM Mandiri Program channeled through UPK Tanjungari in the form of Savings and Loans for Women (SPP); (4) Net Income Business (SHU), SHU is the total deposit service deposited by the member of group fund borrower every month. The SHU dividend/share (cash) is usually done in each month of Ramadhan along with the sharing/ granting cash of voluntary savings of each member; and (5) the processing of food products. The products produced by KWT Mekar Arum consist of beverage products such as specialty natural coffee, ginger coffee, instant ginger, instant turmeric, and kaskara, and food products including banana chips, 'ranginang', 'rangining', 'kremes ubi', 'basreng', 'sale pisang', 'noga', cheesestick, and vegetable 'cireng'. Production is done entirely by each member with the help of KWT in the form of accessing production equipment, capital, and market through the introduction of Mekar Arum KWT products at events of exhibitions held by sub-district, regency, or other institutions.

\section{The Social Role of KWT Mekar Arum Platform and Psychological Space}

Activities carried out together in KWT Mekar Arum raises happiness for fellow members. A place to meet, tell each other stories, and complain about anything including personal things make the members feel at home and pushing away the group impression as a society of formality existence. Odah (57) acknowledged that the 'riungan' which meant gathering with friends was the reason why she was interested and happy to participate in every activity undertaken in KWT Mekar Arum. "At home there is no activity, and if I'm here I am having activities not like at home. I can socialize with my friends here in the group.". Each member is given facilities to plant the yard; the facilities provided in the form of seeds and poly bag. Responsibility comes naturally after a sense of belonging in the group in which the member is part of the group and has the goal of moving forward together. 


\section{Growers of Social Solidarity}

Fellow members of KWT Mekar Arum do not regard each other as strangers. They feel close inside and outside of KWT activities. Group of social funds are set aside for relief funds in the event of death in a member's family, donations when one or more members (or their family's) get ill/sick, and as a source of funding for donations of environmental activities. "The benefits are many, it is family, and it is more binding if it's in a group. If there is a sick member, we visit together to the hospital."(Ati, 59). Cohesiveness is also the reason why Ira Rohyani (26) felt at home to continue joining the group. The initial formation of KWT Mekar Arum is as a platform for program assistance, but during and after the program run, the cohesiveness among the members is intertwined. Cohesiveness is also the reason why Mekar Arum is active again after a long vacuum and able to stand without the help of government programs. All informants whose membership applied a year after the vacuum period of Mekar Arum (2000-2002), claimed that the togetherness seen at KWT Mekar Arum was the first reason they decided to join the group.

\section{Members' Security Provider}

The safety of the members is given to the group in financial terms. The livelihoods of most of the members' husbands are as farmers, farm laborers, and construction workers whose income are often uncertain every month, so that the savings and loan activities can help many members of KWT Mekar Arum. The chairman, Lilis Ciyarsih (41) admitted that savings and loan activities can not only meet the needs of venture capital, but also help members who have irregular (sudden) needs such as paying the hospital cost for sick family members or their children's school fee. "We can save money and we can borrow too. Before, I was confused where to borrow money. Now there is this group."(Dedah, 39). Groups give trust to members through a payment system that does not put pressure of deadline to the borrower. Giving trust to members is one of the attitudes that make members feel secure and give the same trust to the group.

\section{Awards for the Role of each Member}

In addition to distributing the role of members through group organizational structures, KWT Mekar Arum also distributes roles to members through their activities. KRPL activities ranging from breeding as a provider of home input, cultivation, to the marketing of the yard is done together with the members. The responsible members are established through deliberations in the division of nursery garden care tasks and the three demonstration plots belonging to the group (Table 3).

Table 3

Person in Charge of Nursery Garden and Demonstration Plot

\begin{tabular}{|c|c|c|}
\hline No. & Location & $\begin{array}{c}\text { Responsible } \\
\text { Members }\end{array}$ \\
\hline 1 & Nursery Garden & $\begin{array}{l}\text { Lilis, Isum, Juju } \\
\text { Jubaedah, Dedah, } \\
\text { Atin. }\end{array}$ \\
\hline 2 & $\begin{array}{l}\text { Demplot } \\
\text { Tonggoh }\end{array}$ & $\begin{array}{l}\text { Tati, Fatimah, Irma, } \\
\text { Iyam, Mumun, } \\
\text { Ningsih. }\end{array}$ \\
\hline 3 & Demplot Lebak & $\begin{array}{l}\text { Oom, Ati, Odah, } \\
\text { Anah, Cicih. }\end{array}$ \\
\hline 4 & Demplot Ibu Nia & $\begin{array}{l}\text { Nia, Ira, Susi, Cucu, } \\
\text { Yoyoh, Papat, Juju } \\
\text { Juariah. }\end{array}$ \\
\hline
\end{tabular}

Source: Primary Data of Interview Result

According to Ningsih (60), the KRPL program made her feel involved in the group, so that even if she did not play the role of the person in charge in demonstration plot or nursery garden, she would continue to use the assistance well through serious care. "All activities are given a sense of responsibility to move forward. The yard helps us, so that people want to take care of it."(Ningsih, $60)$. Collectivity in marketing the products, recognized members as a big mover of their passion are in charge of managing the yard. Till this date, all members have entrusted the marketing of their yard products to Juju Juariah (44), who collects members'vegetable products every Saturday for later on to be sold at 'Pasar Kaget' Metro, in Bandung every Sunday morning.

\section{The Means of Achieving Goals}

KWT Mekar Arum acts as a mean for achieving group goals. There are three roles developed: First, as a platform or place of learning together (a place to exchange understanding) through regular meetings, practice classes, training and comparative studies. Second, the utilization of the yard as a living stall through the implementation of KRPL program in which each member get 
the garden plant inputs of seeds and polybags for free and sustainably from the group. The group also facilitate the marketing of the products of each member's yard by giving the responsibility of products marketing to one member of the board, Juju Juariah (44) who regularly sells the members' yard products once in a week. Third, increasing the income and welfare of members through saving and loan and processing of agricultural products. The group acts as a platform of activities aimed at improving the welfare of members and their families. Through savings and loans, business and family farming capital can be fulfilled by the members, so that the activities of fulfilling the needs of the families can go on. The process from agricultural products into processed products is also a member's activity which is facilitated by the group, although it is still individual in terms of access to raw materials of production. The increase in member's income apart from the above activities comes from the sale of their yard products.

The conditions in the field are in accordance with Johnson \& Johnson's theory in Sarwono (1999: 5). The group, in this case KWT Mekar Arum, is a place for individuals to interact; each are aware of its membership and other members as part of the group, as well the aware of positive interdependence in achieving the common goal, that is the goal of KWT Mekar Arum. The concept of social capital was put forward by Putnam (1993: 36) in Kusumastuti (2015: 85) which stated that social capital formed from social networks, norms, and beliefs. Thus, KWT Mekar Arum as a social organization has a role in creating social networks among members, and members with people outside members, which they did not have before joining the group.

Regular meetings and group activities carried out continuously were recognized by members to strengthen the communication and cooperation among them. Furthermore, continuous communication and cooperation spark mutual trust in the group as reflected through the division of work tasks, both in the organizational structure and the distribution of tasks in the field. The collectiveness of KWT Mekar Arum is realized by members to bring them a better state of knowledge, skills, and well-being as their common goal. The shared purpose of the members is able to strengthen the norms for mutual help and tolerance among them. The group share not just a friendship, but also family relationships. Based on the real conditions in

\section{Production Machine Helper}

\begin{tabular}{cll}
\hline Informant & \multicolumn{1}{c}{ Name } & \multicolumn{1}{c}{ Production Machine } \\
\hline 1 & Ira Rohyani & Stove, big langseng (steamer), pan, basin, scale \\
2 & Patimah & Scale, pan, knife, gas, stove \\
3 & Lilis Ciyarsih & Grinder, electric scale \\
4 & Iam Mariyam & Stove, gas, scarring machine, flour machine, sealer, knife, skillet \\
5 & Tati Yulianti & Stove, gas, scarring machine, flour machine, sealer, knife, skillet \\
6 & Yani & Stove, gas, scarring machine, flour machine, sealer, knife, skillet \\
7 & Isum Sumanah & Scale, sealer, cheese stick grinder, chips machine, frying pan \\
8 & Juju Juariah & Stove, big langseng (steamer), basin, scale \\
9 & Nia Kurniasih & A set of gas stove \\
10 & Dedah & Electric coconut scar machine, sealer, cylinders gas, regulator, and scale \\
\hline
\end{tabular}

Capital Source

Utilization

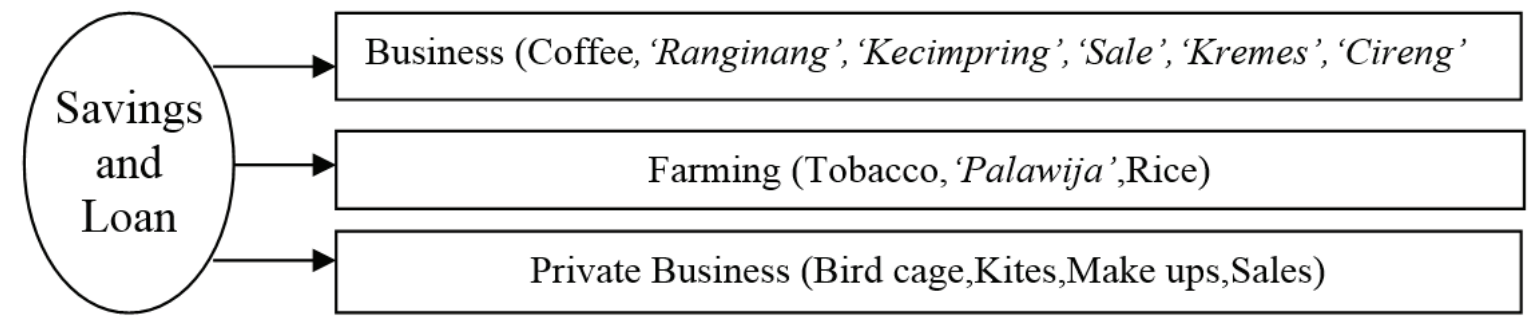

Figure 1.Capital Facilitation of KWT Mekar Arum 
the field, KWT Mekar Arum has mastered the three main pillars of social capital forming: (1) social network; (2) norms; and (3) trust.

\section{Role of KWT Mekar Arum in Business Development}

\section{Facilitating the Provision of Produc- tion Inputs}

Members obtain their raw materials products by purchasing them using their own capital, since the food products they produced are the individual's and not products managed together with the group. In processed food production activities, the group has not yet played a role in providing input directly as it does in the yard activities.

The group receives input production help from the government and then distributes it to the members. Youth Entrepreneurship Training held by Manpower Office of Sumedang Regency in October 2015 invited eleven members of KWT Mekar Arum. Production machine was aided for each participant according to the type of business they distributed through the training with a budget of Rp.2.500.000, - per person (Table 4).

\section{Facilitation of Capital}

Savings and loan activities consisting of savings and loan UPK and savings and loan group members are used as business capital of their processed products, in which some are using savings and loan as a family farming capital. Some members make use of the savings and loan funds as private business capital (Figure 1).

Nia Kurniasih (41), Ira Rohyani (26), Isum Sumanah (44), Iam Mariyam (53), and Lilis Ciyarsih (41) admitted that the existence of savings and loan in KWT Mekar Arum helped fulfilled their business capital needs. For Oom
(58), Yani (41), Tati Yulianti (54) and Iam Mariyam (53), savings and loan funds were used as additional capital for their husband's farming. Dedah (39), utilizing savings and loan funds for his husband's business capital of a birdcage artisans. While Ningsih (60), admitted that savings and loan activities really helped her in running her business as a kite supplier.

\section{Marketing Facilitation}

Those who are able to take advantage of the group marketing facilitation through the exhibition and word of mouth marketing (viral marketing) are as much as four members. "If every participant exhibits, the product rarely comes back again, it is salable." (Nia Kurniasih, 41). Two people market their products by a way of entrusting them in stalls around the village. A total of six members recalled their customers' orders to fulfill the needs of celebration, while direct marketing at each production site is the most widely used marketing method of KWT Mekar Arum members, which is done by as many as eight members (Figure 2).

"Nya hese gitu ari kecimpring mah. Jadi nu garaduh mah ngadaramel dimasarkeunna Neng nu hese... lahh. Ari ngadamel namah Neng gampil" ("It's difficult for 'kecimpring'. So those who have cassava will make their own kecimpring. Making kecimpring is easy, but to market them is hard.") (Ira Rohyani, 26). The narrow span/ space of marketing have forced Rohyani (26), IamMariyam (53), and Yani (41) reduce their production and targetted only for seasonal sale of the fasting month or when there is an order. Dedah (39) and Patimah (50) have even halted their processed production of 'wajit' and 'noga' on the grounds for not being able to market their products, so that the production machine that was given to them is no longer being used for

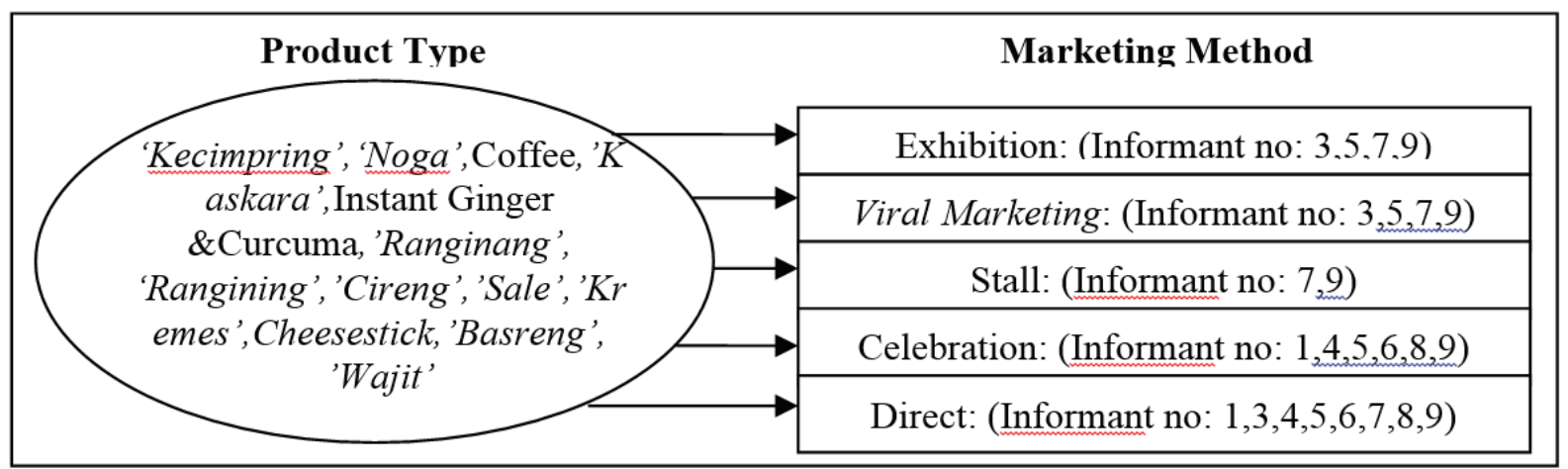

Figure 2. Marketing of Member's Products (Source: Primary Data of Interview Result) 
production since October 2016.

The efforts of KWT Mekar Arum in facilitating the marketing of processed products have not shown tangible results for the members as a whole. Currently, the KWT Mekar Arum has just reached the stage of product marketing through exhibitions that are often held by regencies, sub-districts, or other parties such as universities at certain events. According to the concept of Anoraga (2007: 66) on aspects of business development that includes the field of production and processing, marketing, natural resources, and technology, the role of KWT Mekar Arum has already included the facilitation of the four areas mentioned above. Production and processing is done through the provision of production input for members, even though not in the form of raw materials yet. Natural resources and technology are enhanced through cultivation materials, as well as product processing training followed by members in the group. Marketing efforts is made through the exhibition, although it is not yet able to accommodate the overall marketing of member products.

The Role of KWT Mekar Arum in Improving Family Members' Welfare To Increase of Family's Income.

Thirteen members experienced an increase in the incomes every month.
Lilis Ciyarsih (41) and Nia Kurniasih (41) received additional income from their homes and processed products that have been running continuously. Isum Sumanah (44) admitted that the increasing income derived entirely from her vegetable cireng production activities as the result of the yard she did not sell but used it as a raw material of vegetable cireng production. Tati Yulianti (54), Iam Mariyam (53), Odah (57), Ati (59), Oom (58), Dedah (39), Rini (42), and Yani (41) received additional income from their yard's products selling every week (Table 6). Juju Juariah (44) admitted that KWT Mekar Arum is the door that opened the opportunity for her to start selling in the morning market. Every week she earned a net profit worth of 400,000 Rupiah from selling the yards productions of KWT members and her own. Tati Yulianti, Iam Mariyam, Juju Juariah, and Yani are members who, in addition to utilizing the yard products, also have processed products which they produce seasonally. In the months leading up to Ramadhan, they can earn an additional income of 60,000 to 200,000 Rupiahs more per month from their product sales.

Juju Jubaedah (47), Ningsih (60), and Patimah (50) did not experience an increased income because they did not own a product and did not use the yard for sale, but use it instead for consumption purposes. Ira Rohyani (26) is a passive member who

Table 5

The Increasing of Members' Income

\begin{tabular}{llll}
\hline \multirow{2}{*}{ No. } & \multirow{2}{*}{ Member Name } & \multicolumn{2}{c}{ Income Increases } \\
\cline { 3 - 4 } & \multicolumn{2}{c}{ Before } \\
\hline 1 & Lilis Ciyarsih & 0 & 600.000 \\
2 & Tati Yulianti & 0 & 580.000 \\
3 & Nia Kurniasih & 0 & 1.800 .000 \\
4 & Isum Sumanah & 0 & 300.000 \\
5 & Iam Mariyam & 280.000 & 340.000 \\
6 & Juju Juariah & 280.000 & 1.880 .000 \\
7 & Odah & 400.000 & 460.000 \\
8 & Ati & 0 & 120.000 \\
9 & Oom & 140.000 & 260.000 \\
10 & Dedah & 0 & 48.000 \\
11 & Rini & 900.000 & 1.100 .000 \\
12 & Yani & 900.000 & 980.000 \\
13 & Ira Rohyani & 280.000 & 330.000 \\
14 & Juju Jubaedah & 105.000 & 105.000 \\
15 & Ningsih & 1.500 .000 & 1.500 .000 \\
16 & Patimah & 640.000 & 640.000 \\
\hline
\end{tabular}

Source: Primary Data of Interview Result 
experienced an increase income due to the production of kecimpring that is still running.

\section{Fulfillment of Educational/School Fee}

Revenues generated by members through the group are utilized for various family needs, including educational/school needs. Nia Kurniasih (41) through her earnings can now help her husband to send her first son, who is currently in the final semester, to study at Winayamukti University; and to finance her second daughter's education in elementary school. "(the money goes) for children's school, to pay this and that, for daily necessities, the rest is for others." (Nia Kurniasih, 41). In line with Nia Kurniasih, Juju Juariah (44) and Isum Sumanah (44) also utilize the additional income as the fulfillment of the tuition fee of their children. Sustainable production activities are the reason for the high income of members' which enable them to fulfill their children's educational expenses. Costs in education include direct costs and indirect costs (Fattah, 2004). Direct costs include the costs incurred for the purposes of teaching and learning activities, such as the cost of education filled by Nia Kurniasih, Juju Juariah, and Isum Sumanah.

Whereas, indirect costs are sum of money paid for activities outside learning cost, such as students' pocket money and the purchase of school equipment, which is the cost incurred by Dedah (39) for her son. Similarly, Iam Mariyam (53) utilizes the proceeds from the sale of food products and yard to finance the educational needs of the child in primary school. "Well nope, (it won't be used) not until paying for education fees. Since production is not routinely, but seasonal (Yani, 41). Another case is Yani (41) whose youngest child is now sitting in high school. Her own ranginang and rangining production which is only active in certain months does not play a role in fulfilling his child's school costs. The fulfillment of the educational needs is fully funded by the income from the farming of her husband and hers.

\section{Fulfillment of Health Fee}

With regards to the fulfillment of healthcare costs, the increased revenue received by KWT Mekar Arum members is also used to help fulfill their healthcare costs. For Tati Yulianti (54), income from her work in the group can help her pay her doctor and get medication from the clinic for her illness. It is recognized as an effort to fulfill her health needs and her family's. "It is rare for me to go to the doctor. The clinic is also suitable and enough for me. Alhamdulillah." (Tati Yulianti, 54). For Ati (59), Oom (58), and Odah (57) the income they receive from selling vegetables from the yard each week can be used for daily living needs, including to buy medicine from stalls. At the time they or family members are in need, they can fulfilled these needs without having to rely on money coming from their respective husbands.

\section{Improving the Quality of Relationships between Family Members and Family Functions}

The role of husbands toward their wife's membership in KWT Mekar Arum is as a supporter, both morale and energy assistance. Cecep Apendi (28), husband of Ira Rohyani (27) says about his wife's membership in KWT that he will always support every activity his wife performs as long as the activity has a positive impact. He said that the activities his wife did after training, which is processing kecimpring for sale, can help her meet the daily needs of their family. The support from husband to wife also came from Engka Wahyudin (62), who set KWT as a source of knowledge for his wife, Odah (57), especially for the science of cultivation. Besides in the form of morale, members' husbands also provide support in the form of power at KWT Mekar Arum activities. KWT Mekar Arum nursery garden is made in the form of a greenhouse with medium framework arranged using bamboo. Members' husbands work for five days for the completion of the development of nursery gardens and fish ponds owned by KWT. "My husband helped me making the nursery garden, because us woman can't make it from bamboo, so it's the man's job to do it (Dedah, 39)."

The assistance from the husband is also felt by Nia Kurniasih (41), Nia Kurniasih's increasing activities after joining KWT is in line with the increased cohesiveness between her and her husband, Supendi (51), in taking care of the yard to help him get raw materials for the production of processed foods in their home. "The change is active, if there is work on Sunday, my husband will do the cleaning, it's ok to exchange roles." Said Toto (52), husband of Juju Juariah (44)). The support addressed from the husband to the wife is a reflection of the socialization function of the family, in which the family as a platform of cultural values inculcation so that each 
member is able to actualize himself/herself in every action both in the family and in the middle of social life (Ritonga, 1996).

Compared with the concept of Family Welfare BKKBN Year 2005 which mentioned 21 points indicator of prosperous family including basic needs fulfillment, social psychological, and development, hence role of KWT Mekar Arum in field does not represent all indicator of those concepts. The Role of Women Farmer Group (KWT) is specific. Members of KWT Mekar Arum consist of wives, in line with Susanto's (1985: 75) theory in which the role of women in the family is as wives, mothers for children, and husband's partners. So taking care of the family is their main task. Making a living to meet every family's needs is the husband's main job. Income aid from wives is solely as a complement to the husband's income. Further relation to the conditions in the field, income earned through the group is utilized by members to meet the educational needs of children and family's health. Their active activities in the group are also able to improve the quality of family relationships and functions, especially through the support of husbands. Members of KWT Mekar Arum have been able to reflect the concept of a prosperous family from Milligan et al. (2006) in Riza (2014: 31) on the components of prosperous families that include income, education, health, and the quality of relationships between family members and family functions.

\section{Obstacles in KWT Mekar Arum}

The diversity of the processed products business in the group becomes a problem in the supply of production inputs. Processed products have been owned by members before they join the KWT Mekar Arum. This is one of the considerations of the group to maintain the existence of the thirteen types of food products, and on the other hand has not been able to collect input provision. In addition, obstacles in marketing are also a problem admitted by the members, and recognized by the chairman. According to Lilis Ciyarsih (41), there is an understanding of members that the group has not been able to provide more benefits for members, especially for some product owners.

\section{Conclusions}

Socially, KWT Mekar Arum acts as a platform and a psychological space, social solidarity growers, security providers, rewards through the role of each member, and as a means of achieving the goal (platform or place to learn together/exchange understanding, the use of the yard as a living stall, increase income and welfare of members through savings and loans, and processing of agricultural products). Related to business development, KWT Mekar Arum plays a role in facilitating the provision of production inputs, capital facilitation, and marketing facilitation. In real terms, there are still members who have not felt the role, because the facilitation is not as expected and unsustainable.

The role of KWT Mekar Arum in improving family welfare can be seen from the increase of family income, the fulfillment of education cost, the fulfillment of health cost, and the improvement of the quality of the relationship between family member and family function of each member. However, those who have not been active in productive activities, have not felt much the role of the KWT. The openness and courage of the board in conveying ideas to members are needed to bring the group towards collective efforts. It is a good idea for a joint venture to be conveyed explicitly to members and immediately implemented seriously. Optimizing high mobility of the board is needed to get the aid channel for the opening of KWT Mekar Arum door in running the joint business.

\section{References}

Anoraga, P. (2007). Pengantar Bisnis. Pengelolaan Bisnis dalam Era Globalisasi. Jakarta. Rieneka Cipta.

BPS. (2016). Produk Domestik Bruto Indonesia Triwulanan 2012-2016. Jakarta. Badan Pusat Statistik.

BPS Kabupaten Sumedang. (2014). Kabupaten Sumedang dalam Angka Tahun 2014. Sumedang. BPS Kabupaten Sumedang.

C. Tara Satyavathi, Ch. Bharadwaj, P.S. Brahmanand. (2010). Role of Farm Women in Agriculture. Journal Asian Institute of Technologi, Vol 14, Issue 3, 2010

Fattah, Nanang. (2004). Ekonomi \& Pembiayaan Pendidikan. Bandung. PT Remaja Rosda karya.

Kusumastuti. (2015). Modal Sosial dan Mekanisme Adaptasi Masyarakat Pedesaan dalam Pengelolaan dan Pembangunan Infrastruktur. Jurnal Sosiologi. 20:81-97.

Pemerintah Desa Margaluyu. (2016). Profil Desa Margaluyu Tahun 2016.

Renyasih, I Setiawandan G Kurnia. (2004). 
Perspektif Gender dalamPengelolaan Irigasi di Jawa Barat. Pusat Dinamika Pembangunan Unpad, Bandung.

Ritonga, Ahmad Husein. (1996). Fungsi Keluarga dalam Meningkatkan Kualitas SDM Daerah Sumatera Utara. Dinas Pendidikan dan Kebudayaan RI. Medan.

Riza, dkk. (2014). Kesejahteraan Peserta dan Bukan Peserta Program Gerakan Perempuan untuk Optimalisasi Pekarangan (GPOP). Jur. Ilm. Kel. \&Kons. 7:30-39.

Sarwono, S. Wirawan. (1999). Psikologi Sosial Kelompok dan Terapan. Jakarta. PT. Balai Pustaka.

Setiawan, I.,Sumardjo, Arif Satriadan P Tjitropranoto. (2015). Strategi Pengembangan Kemandirian Pelaku Muda Agribisnis "Brain Gain Actors" di Jawa Barat. Mimbar Volume 31, Nomor 2 (Desember, 2015): 409-418.

Setiawan, I. (2006). Transformasi Peran Wanita Tani Ke arah Pengembangan Kualitas SDM di Pedesaan Jawa Barat. Jurnal Kependudukan Unpad, Bandung.

Sri Hidayati Djoeffan. (2001). Gerakan Feminisme di Indonesia: Tantangan dan Strategi Mendatang. Mimbar No. 3 Th.XVIIJuli - 284 September 2001
Susanto, A.S. (1985). Pengantar Sosiologi dan Perubahan Sosial. Bandung. Bina Cipta.

Terri Raney, Gustavo Anríquez, Andre Croppenstedt, Stefano Gerosa,Sarah Lowder, Ira Matuscke and Jakob Skoet. (2011). The role of women in Agriculture. Agricultural Development Economics Division. The Food and Agriculture Organization of the United Nations. www. fao.org/economic/esa.

Vitayala H, Aida. (2010). Pemberdayaan Perempuan dari Masa ke Masa. IPB Press, Bogor.

Vivin Ervinawati, Fatmawati dan Endang Indri. (2015). Peranan Kelompok Wanita Tani Perdesaan Dalam Menunjang Pendapatan Keluarga (Di Dusun Beringin Desa Sungai Rengas Kecamatan Sungai Kakap, Kabupaten Kubu Raya Provinsi Kalimantan Barat). Jurnal Tesis PMIS-Untan, 2015.

Yulianita. (2001). Media Massa dan Gaya Hidup Wanita. Mimbar No. 3, Th.XVII. Juli - September 2001.

Wiradi. (2009). Seluk Beluk Masalah Agraria, Reforma Agraria dan Penelitian Agraria. Yogyakarta. STPN Press. 